\title{
"STUDY ON NON ALCOHOLIC FATTY LIVER DISEASE IN TYPE 2 DIABETES MELLITUS WITH CLINICAL CORRELATION"
}

\author{
JaseemAnsari , Roshan M \\ (Father Muller Medical College, Mangalore)
}

\begin{abstract}
BACKGROUND

Diabetes Mellitus (DM) can alter hepatic morphology and physiology ${ }^{I}$. Recently liver disease has been recognized as a major complication of type 2 diabetes mellitus (T2 DM). There is high prevalence of Nonalcoholic fatty liver disease (NAFLD) in individuals with T2 DM. Obesity is also a common and well documented risk factor for NAFLD. There is an epidemic rise in T2 DM, obesity, and hyperlipidemia in the country. A disease practically unheard a few years back, is now considered one of the most common causes of chronic liver disease in the world ${ }^{3}$. The prevalence of NAFLD is rising in India. NAFLD begins as mild steatosis, develops into non-alcoholic steatohepatitis (NASH) which can progress to cirrhosis and even hepatocellular carcinoma ${ }^{2}(H C C)$ making early detection and prevention of diabetic liver disease important.

OBJECTIVES
\end{abstract}

To study the clinicopathological profile of hepatic involvement in T2 DM and correlate between them.

\section{MATERIALS AND METHODS}

The study is a descriptive prospective study of the patients admitted in Father Muller's Medical College with T2 DM conducted over a period of 18 months.

The study includes 100 patients diagnosed with T2 DM. These patients will be elevated by a detailed history including the age, sex, location, duration of diabetes, history of previous illness, medication they were currently taking. Clinical examination includes anthropometric measurements including height and weight and thus the body mass index (BMI), signs of insulin resistance-central obesity, xanthelesma, acanthosis nigricans .Investigations include abdominal ultra-sonography (USG) for fatty liver, glycosylated hemoglobin (HbAlc) ,liver function test (LFT) and lipid profile .Results were analyzed and compared.

\section{RESULTS}

The prevalence of NAFLD among diabetes in our study was found to be $26 \%$.It was found to be more common in the fourth decade of life with equal distribution among men and women. Among the patients with NAFLD 53.6\% were associated with hypertension (HTN), $75 \%$ with dyslipidemia and $19 \%$ with BMI $>19 \% .38 \%$ of the patients with NAFLD were found to have elevated alaninetransaminase (ALT) and 26\% hadelevated aspartate transaminase (AST). $73 \%$ of the NAFLD patients had elevated cholesterol.26\% of the patients in our study were found to have sonological features suggestive of NAFLD.

\section{CONCLUSION}

This study demonstrates and clinically correlates the cluster of abnormalities /risk factors like hypertension, obesity, duration of diabetes with NAFLD.The implication of the study is that diabetics are at a higher risk of developing NAFLD and its related complications.

\section{INTRODUCTION}

NAFLD is the most common liver disease and the third leading indication for liver transplantation ${ }^{1}$. The prevalence of NAFLD has been reported to be $15-30 \%$ in the general population and in T2 DM population, the prevalence is $70-75 \%{ }^{2}$. NAFLD has been proposed as one of the components of metabolic syndrome (MS) ${ }^{4}$. It has been found to be a composite of confirmed cases with central obesity, T2DM and dyslipidemia. Studies have shown the major role of obesity and insulin resistance in NAFLD ${ }^{5}$. However, regardless of BMI, the presence of T2 DM significantly increases the risk and severity of NAFLD ${ }^{6}$. Only recently liver disease has been recognized as a major complication of T2 DM with increased mortality rates for cirrhosis greater than that 
for cardiovascular disease ${ }^{8}$. Insulin resistance plays a central pathogenic role in both T2 DM and NAFLD with the latter being considered as the hepatic manifestation of the $\mathrm{MS}^{9}$.

\section{OBJECTIVE OF THE STUDY}

To study the clinicopathological profile of hepatic involvement in T2 DM and correlate between them.

\section{REVIEW OF LITERATURE}

NAFLD was practically unheard a few years ago, but is now considered one of the most commonliver disorders in the world ${ }^{8}$.It may be the most common cause of liverenzyme elevation in adults as well as one of the leading cause for cirrhosis in the world.The prevalence of NAFLD has increased in joint with the epidemics of obesity and T2 DM, which are the major risk factors for NAFLD ${ }^{10}$. Whereas the association of T2 DM with microvascularcomplications and macro-vascular disease is well established.

Theassociation of T2 DM with NAFLD is a recently recognized entity and less well known ${ }^{10}$. There is evidence that patients with NAFLD who have T2 DM particularly at a high risk of developing cirrhosis compared with those who donot have diabetes. Although cardiovascular disease is the majorcause of excess morbidity and mortality inT2 DM, liver failuremay also be a threat to patients with T2 $\mathrm{DM}^{12}$.

NAFLD is characterized by fatty infiltration of the liver, mostly in the form of triglycerides, which exceeds $5 \%$ of the liver weight.NAFLD is histologically similar to alcoholic liver disease (ALD), but itoccurs in the absence of excessive alcohol consumption and is not dueto other identifiable causes of fatty liver ${ }^{13}$.

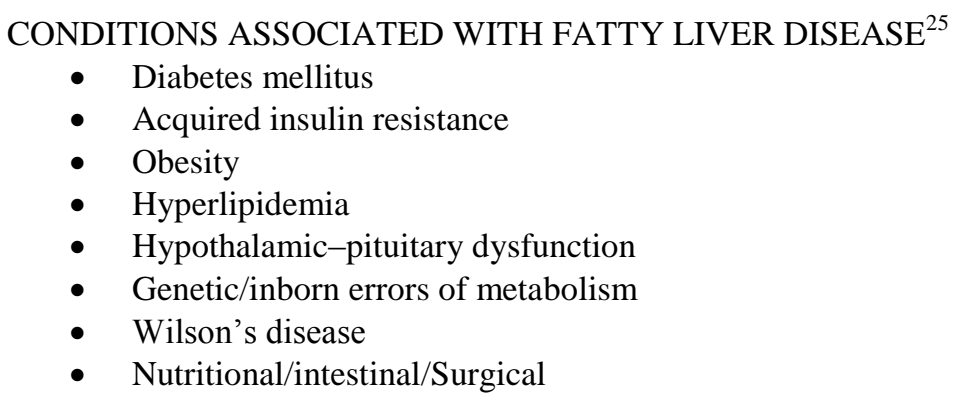

NAFLD represents a spectrum of clinical-pathologicalfeatures ranging from simplesteatosis, which is characterized by fatty infiltration only to non-alcoholic steatohepatitis (NASH), which is characterized by inflammation and hepatocellular injury with orwithout fibrosis and cirrhosis. Most with NAFLD have an increase inliver fat content alone and some developNASH that can progress to cirrhosis.

\section{PREVALENCE}

Data from the Dallas HeartStudy suggested that about one-third of the population of Dallas County, Texas had hepatic steatosis ${ }^{25}$. This study used proton magneticresonance spectroscopy (MRS) to measure liver fat and definedsteatosis as hepatic triglyceride content $>5.5 \%$. Having diabetes carries an even higher risk. Sixty-two per cent ofsubjects in the Dallas Heart Study who had either known diabetes had hepatic steatosis.

As most who have NAFLD have no specific signs or symptoms, it goes unnoticed. In clinical practice,elevated aminotransferase levels, especially ALT, are considered a marker for liver disease ${ }^{17}$. However, manypatients who have NAFLD do not have elevated levels. In the DallasHeart Study, 79\% of those with hepatic steatosis had normal ALTlevels. Making thematter of establishing the diagnosis of NAFLD even more complicatedis that aminotransferase levels do not necessarily correlate with theseverity of NAFLD. ALT levels may be normal in the presence ofadvanced fibrosis or cirrhosis ${ }^{19}$. Thus, a normal ALT does not excludesteatosis and does not ensure the absence of underlying advanced liverdisease ${ }^{21}$.

Therefore, since non-invasive methods of detection were used in these epidemiological studies, the prevalence of pure steatosisversus more advanced stages of disease such as steatohepatitis,fibrosis or cirrhosis is unknown ${ }^{28}$.

\section{SYMPTOMS}

As with many other types of CLD, mostpatients with NAFLD (48-100\%) are asymptomatic.The liver disease is often discovered incidentallyduring routine laboratory examination when a hepaticpanel reveals an elevated 
ALT level. NAFLD isthe most common cause for unexplained persistent elevation of ALT levels once

hepatitis C and other CLD have been excluded ${ }^{25}$. When symptoms occurthey are usually nonspecific. Vague right upper quadrantabdominal pain, fatigue, and malaise are the most common. Rarely, pruritus, anorexia, and nausea may develop. Jaundice, abdominal distension (ascites), gastrointestinal bleeding, and confusion (encephalopathy) are all indicative of advanced liverdisease (decompensated cirrhosis), occurring late in thecourse ${ }^{22}$.

\section{SIGNS}

There are no pathognomonic signs of NAFLD. Obesity is the most common abnormality on physical examination, occurring in $30-100 \%$ of patients in various cross-sectionalstudies ${ }^{26}$. Hepatomegaly has been reported in up to $75 \%$ of patients in several studies. The prevalence of hepatomegaly may increase to $95 \%$ when assessed by USG. Of the various stigmata, spidernevi and palmar erythema are the most common .Muscle wasting may occur as liver disease becomes moreadvanced but is often underestimated due to edema and preexisting obesity ${ }^{27}$.

\section{LABORATORY FINDINGS}

Mild to moderate elevation of serum aminotransferases (ALT and AST) is the most common and often the only laboratory abnormality found in patients with NAFLD ${ }^{29}$. There is no significant correlation between the degree of serum aminotransferase elevation and the histologic severity of hepatic inflammation or fibrosis . Unlike those with alcohol-induced steatohepatitis, who typically manifest disproportionate increases in the AST level relative to the ALT level, patients with NAFLD usually haven AST/ALT ratio $<1$.

The AST/ALT ratiotends to increase with the development of cirrhosis, thuslosing its diagnostic accuracy. Serum alkaline phosphatase (ALP) may also be slightly elevated in aboutone-third of patients. Hyperbilirubinemia, hypo-albuminemia, and prolongation of the prothrombin time (PT) are noted infrequently and generally only seen once liver failure has become established. Elevated serum lipid profiles and glucose concentrations are also common in NAFLD patients, reported in 25 to $75 \%$ of cases.

A small percentage of patients with NAFLD may have a low-titer $(\leq 1: 320)$ antinuclear antibody (ANA) positivity $^{25}$. The role of iron in the pathogenesis ofNAFLD remains controversial.

It is important to exclude secondary causes of hepatic fat so that the diagnosis of primary NAFLD can be made reliably. Hepatitis $\mathrm{C}(\mathrm{HCV})$ and alcoholic liver disease are particularly important because of the high prevalence of these two hepatotoxic agents ${ }^{28}$.HCVcan cause histologic changes that closely resemble NAFLD, thus serologic testing to exclude viral hepatitis has become a pre-requisite for the diagnosis of NAFLD ${ }^{29}$.

By its very definition, the diagnosis of NAFLD cannot be made in the settingof excessive alcohol consumption. However, there is noconsensus among investigators concerning what is an excessiveamount of alcohol and thus there are no published and universally accepted threshold levels. It is generally believed that a fatty liver does not develop with alcohol.

\section{IMAGING}

Several noninvasive imaging techniques, including USG, computed tomography (CT), and magnetic resonance imaging (MRI), can identify hepatic steatosis and have been advocated as diagnostic tests for NAFLD ${ }^{26}$. USG is the most commonly used. The sonographicfindings of diffuse fatty change include a diffuse Hyperechoic echotexture (bright liver), increased liver echotexture compared with the kidneys, vascular blurring and deep attenuation. Fatty infiltration of the liver produces a low-density hepatic parenchyma on CT scanning. In a direct comparison of CT with USG, USG was found to be more sensitive in detecting fatty change. However, when fatty change is patchy or focal, CT scan and MRI are superior to USG. Also, when a semi quantitative assessment is required or when multiple comparative studies are planned over time, CT is superior to US.

MRS is a newer innovative radiologic technique allowing one to examine the resonance frequencies of all proton species within a region of interest and is being investigated as a means of obtaining a more quantitative assessment of fatty liver infiltration.

Despite the utility of these imaging modalities in the diagnosis of diffuse fatty disorders of the liver, none is sufficiently sensitive to detect hepatic inflammation, fibrosis or cirrhosis. 
In a prospective study evaluating therole of different radiological modalities in establishing thediagnosis of NASH, neither USG, CT, nor MRI was able todetect the presence of hepatocyte ballooning, Mallory'shyaline, or fibrosis, which are all important features in thediagnosis of NASH. With the inability to distinguishsimple steatosis from steatohepatitis and stage the severityof injury, liver biopsy remains the best diagnostic test for $\mathrm{NASH}^{31}$.

\section{LIVER HISTOLOGY}

The lack of effectivemedical therapy for NAFLD and risks associated withbiopsy are arguments proposed against obtaining tissue sampling ${ }^{30}$. Nevertheless, liver biopsy is the only accuratemethod for the diagnosis ofNASHand the only meansto determine the severity of liver damage and long-term prognosis.

The histological features of NAFLD are indistinguishable from those of alcohol-induced liver disease. There are two lesions associated with NAFLD:

(i) Predominantlymacro vesicularsteatosis alone

(ii) Predominantlymacro vesicularsteatosis

And varying amounts of cytological ballooning and spotty necrosis, scattered mixed

Neutrophilic-lymphocytic inflammation, glycogen nuclei, Mallory's hyaline, and per sinusoidal fibrosis (NASH). All of the features of steatohepatitis are not present in every instance of steatohepatitis. The severity of steatosis can be graded on the basis of the extent of involved parenchyma.

Given the association of NAFLD with metabolic syndrome (MS), obesity and T2 DM the prevalence of NAFLD and NASH are increasing. Within the NAFLD spectrum, only patients with histologically proven NASH develop progressive liver disease. Progression seems more likely in the setting of diabetes, insulin resistance and other pre- existing conditions.

Hence it is reasonable to expect that early diagnosis of NAFLD and early intervention which would prevent progression to more serious stages

\section{METHODOLOGY \\ SOURCE OF DATA}

The data was collected from both outpatients and inpatients in Father Muller's Medical College Hospital from 1st August 2013 to 1 st August 2014.

\section{METHOD OF DATA COLLECTION \\ STUDY DESIGN}

The study is a descriptive prospective study of the patients in Father Muller's Medical College with T2 DM.

The study will includes 100 patients with equal sex ratio, diagnosed with T2 DM.These patients was evaluated by a detailed history including the age , sex ,location, duration of diabetes, history of previous illness , medication they were currently taking. Clinical examination includes anthropometric measurements including height and weight and thus the BMI, signs of insulin resistance-central obesity, xanthelesma, acanthosisnigricans .Investigations include abdominal USG for fatty liver, HbA1c, LFT and lipid profile .Results will then be analyzed and compared.

\section{INCLUSION CRITERIA}

(1) Known cases of T2 DM ('3 years) patients of both sexes between the age group of 25 to 80 .

\section{EXCLUSION CRITERIA}

(1) Known history of chronic viral hepatitis

(2) Individuals with alcohol consumption

(3) History of drug intake that can cause fatty liver.

(4) Patients with nephropathy.

(5) Patients in congestive cardiac failure (CCF).

(6) Patients on insulin.

DATA ANALYSIS: Data was analyzed by frequency,percentage, mean and standard deviation.

\section{RESULTS}

\section{PREVALENCE OF NAFLD}




\section{USG-FATTY LIVER}

\begin{tabular}{|c|l|l|}
\hline & \multicolumn{1}{|c|}{ Frequency } & \multicolumn{1}{|c|}{ Percent } \\
\hline N & 74 & 74.0 \\
Y & 26 & 26.0 \\
Total & 100 & 100.0 \\
\hline
\end{tabular}

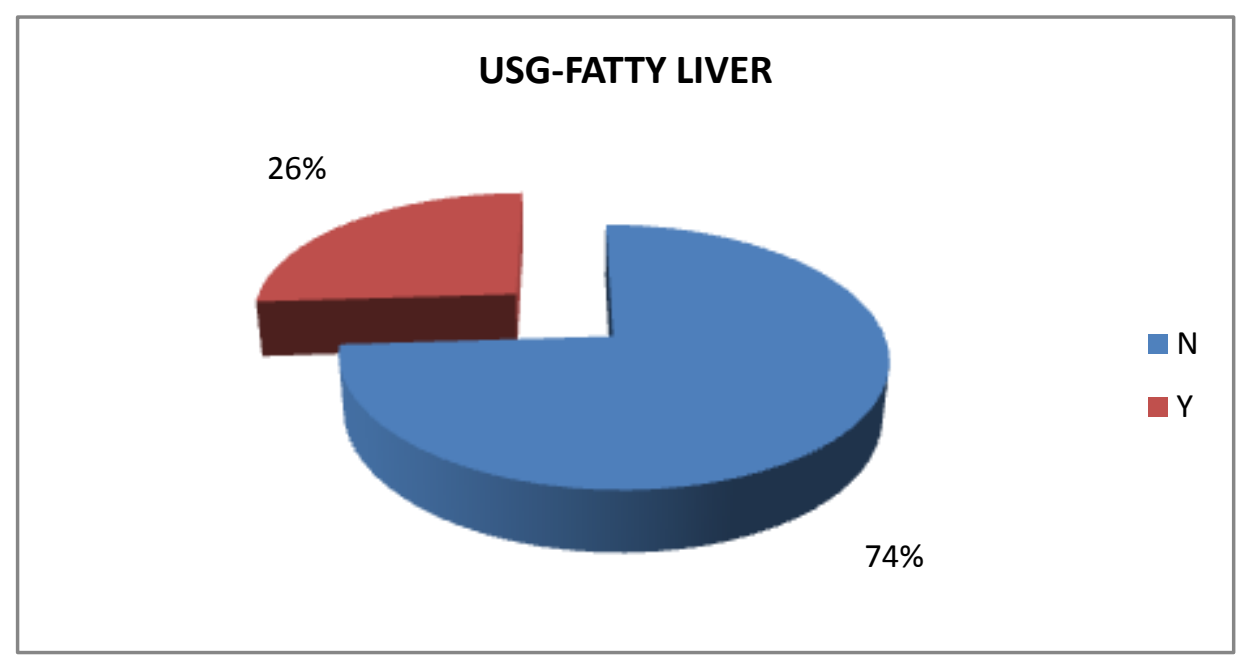

The prevalence of NAFLD among the total number of cases included in the study was found to be $26 \%$

\section{AGE DISTIBUTION}

AGE * USG-FATTY LIVER Cross tabulation

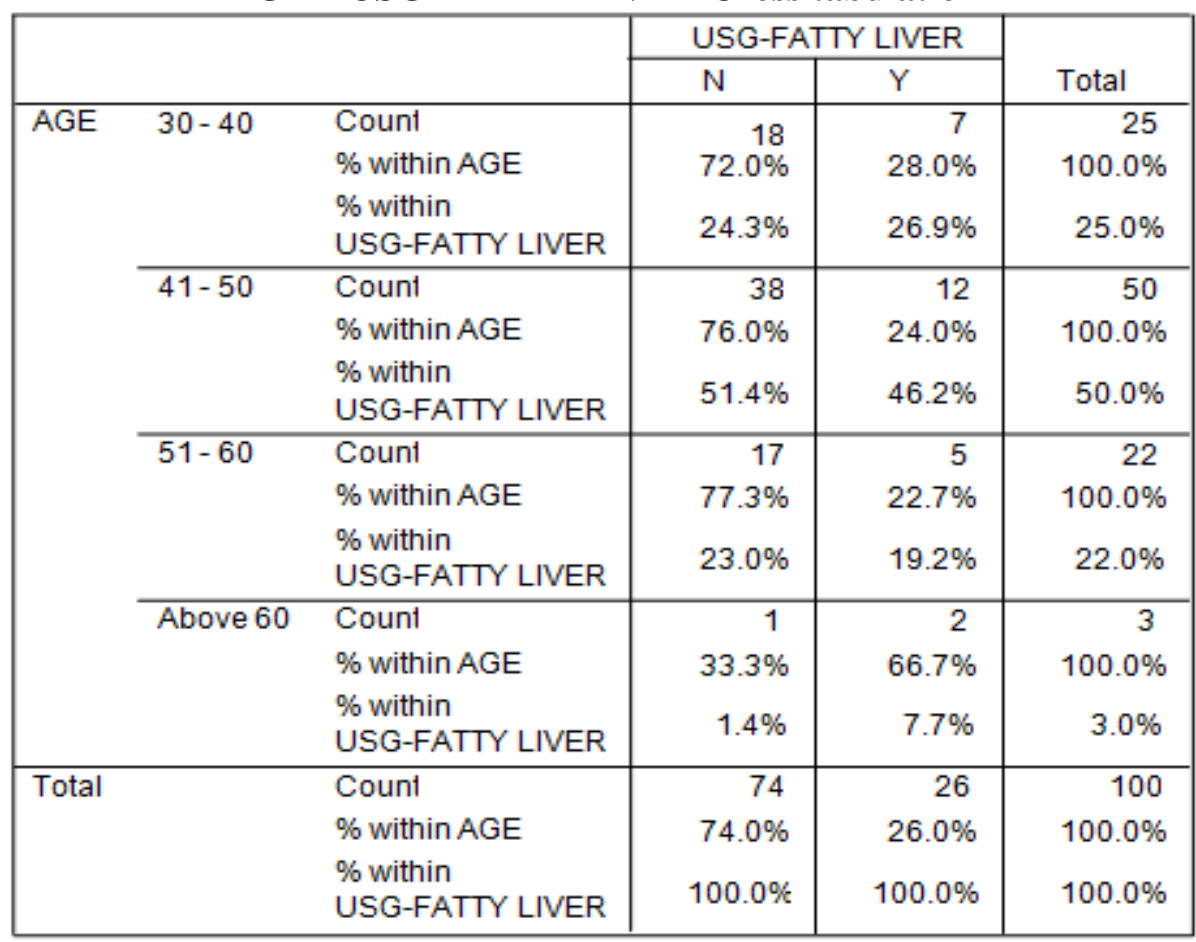




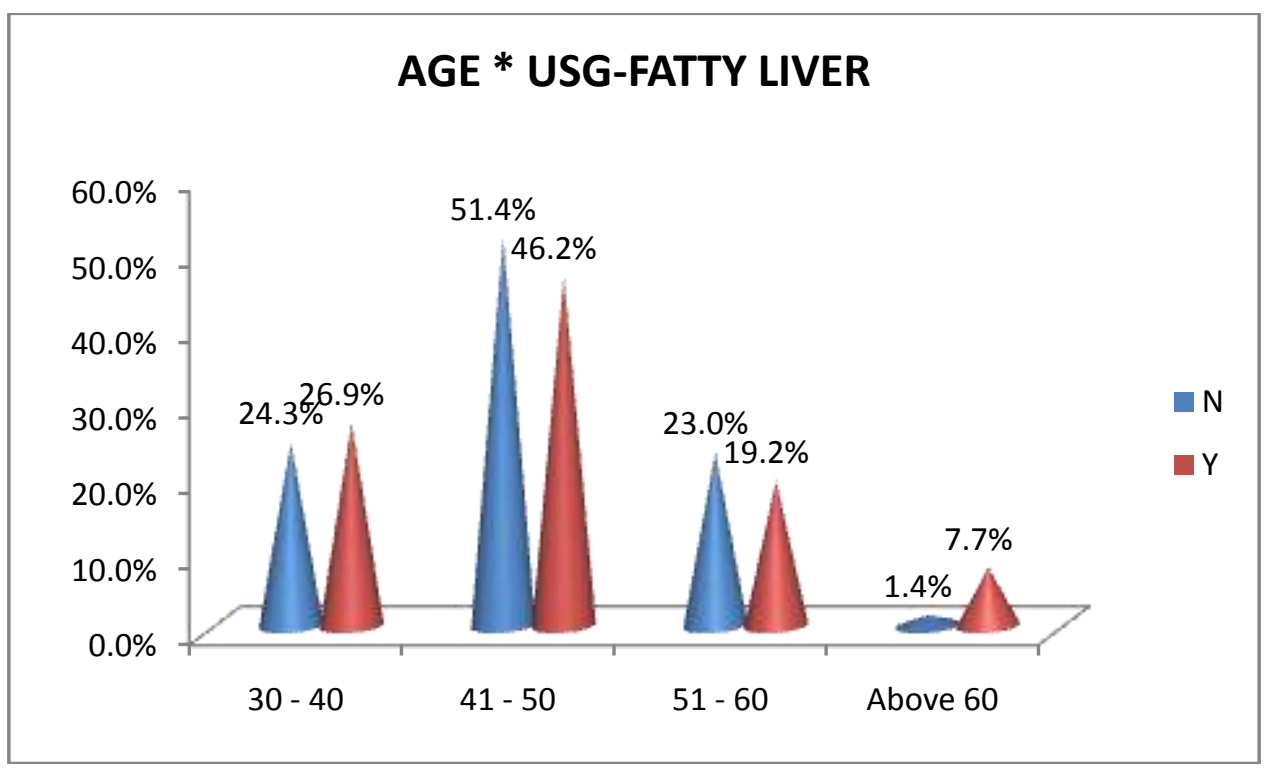

The prevalence of NAFLD was found to be higher in the fourth decade SEX DISTRIBUTION

SEX * USG-FATTY LIVER Cross tabulation

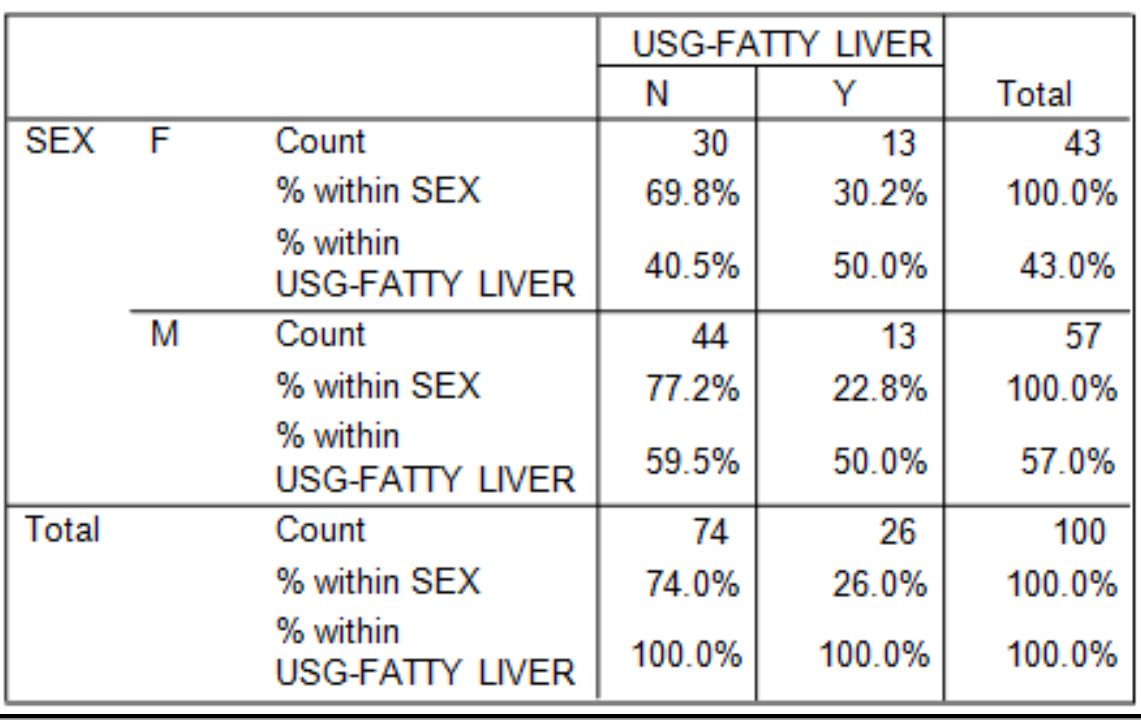

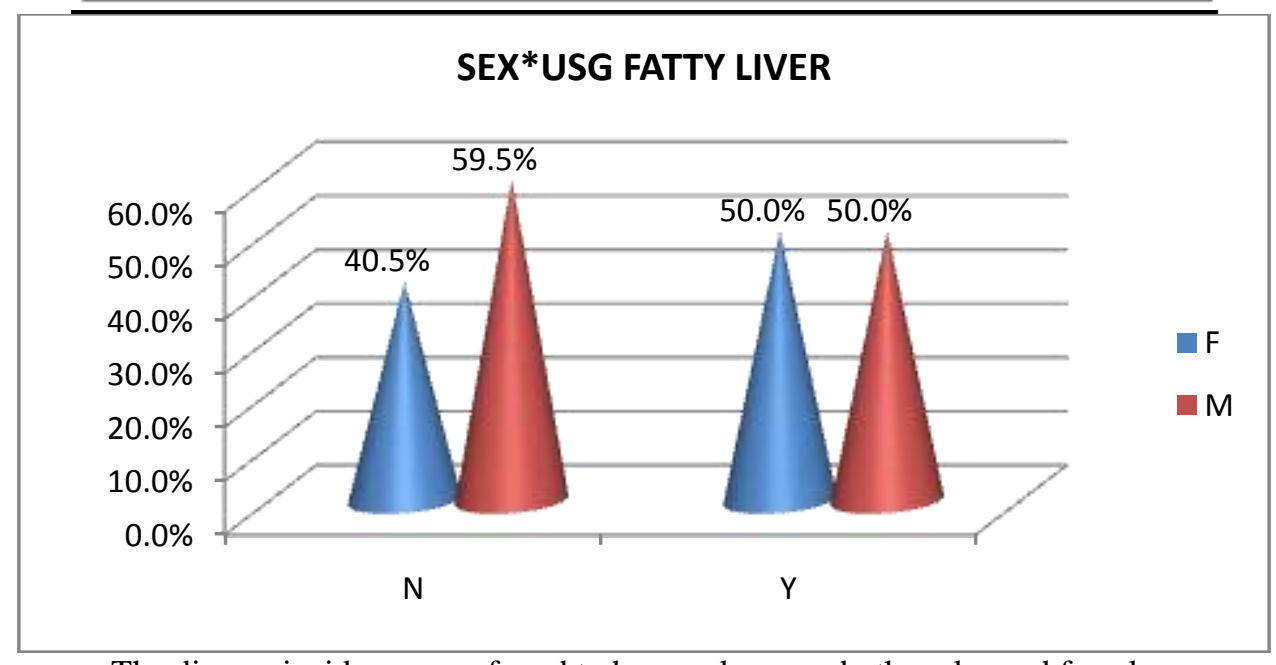

The disease incidence was found to be equal among both males and females. 


\section{DURATION OF DIABETES}

DURATION OF DM * USG-FATTY LIVER Cross tabulation

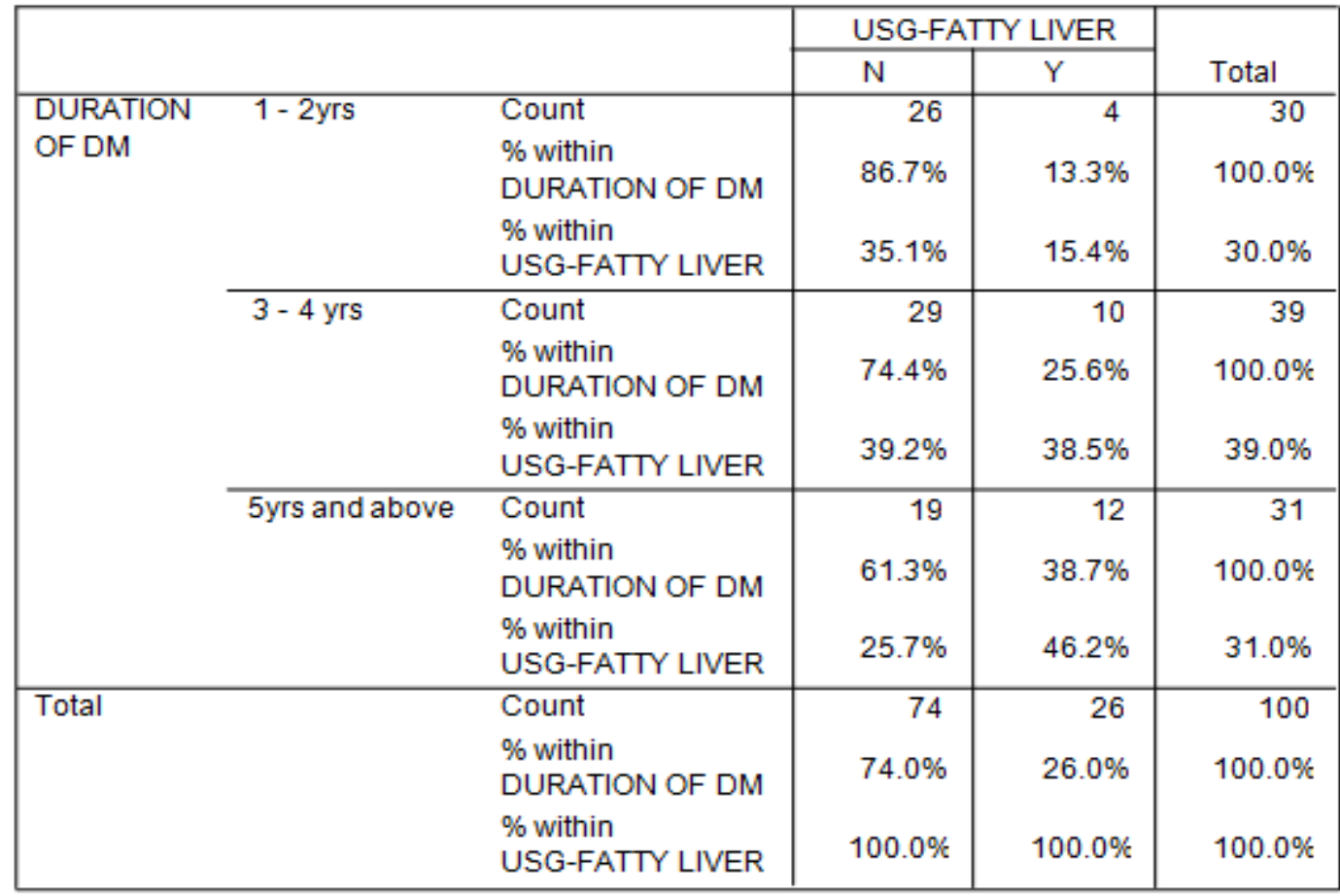

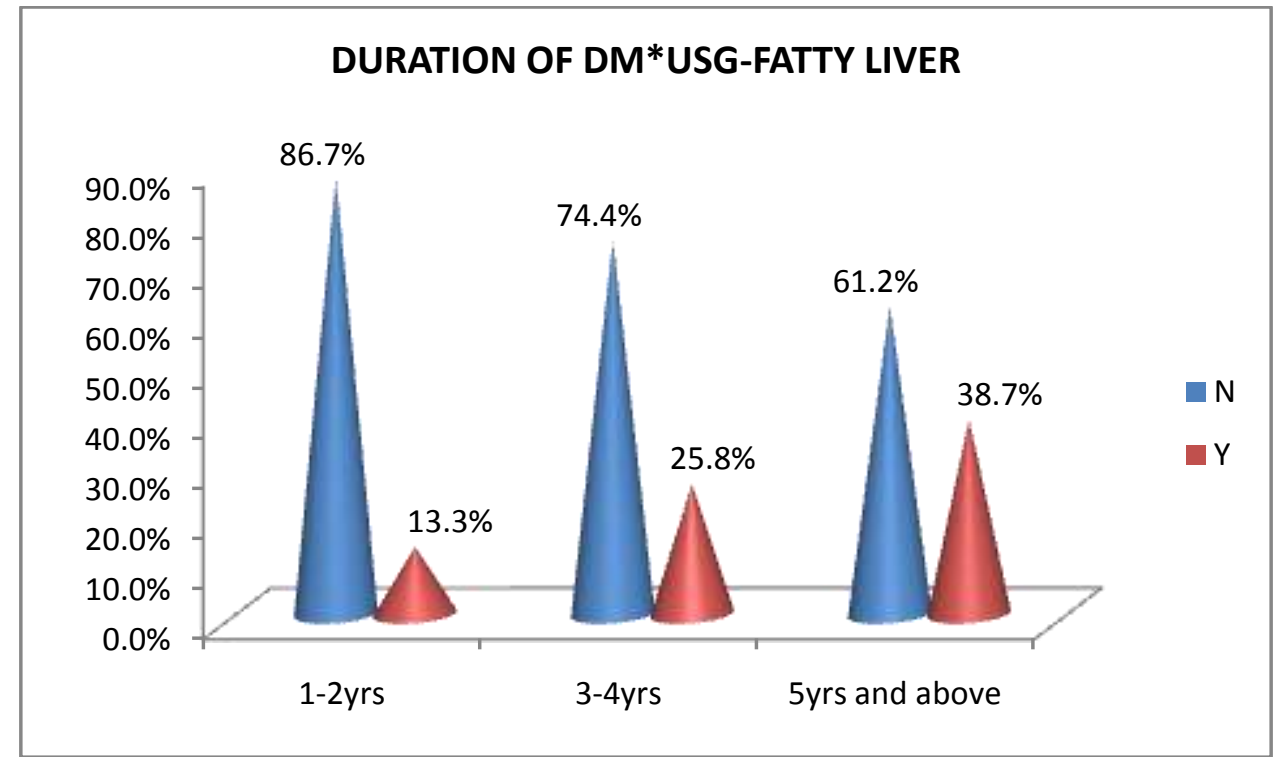

The prevalence of NAFLD was found to be more among the patients with more than 2 year duration of diabetes

\section{SIGNS AND SYMPTOMS}

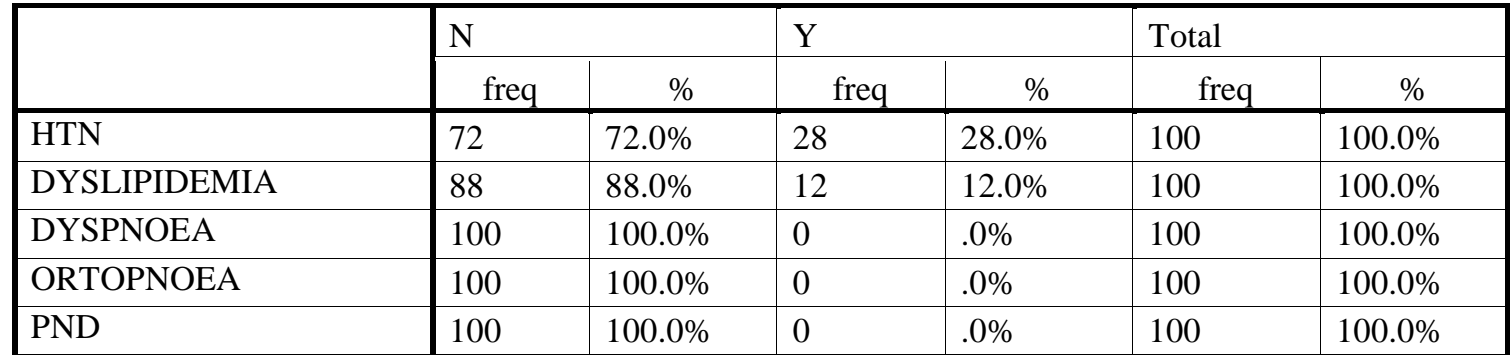


Study On Non Alcoholic Fatty Liver Diseases in Type 2 Diabetes Mellitus With Clinical Correlation

\begin{tabular}{|l|l|l|l|l|l|l|}
\hline HEAT INTOLERANCE & 100 & $100.0 \%$ & 0 & $.0 \%$ & 100 & $100.0 \%$ \\
\hline COLD INTOLERANCE & 100 & $100.0 \%$ & 0 & $.0 \%$ & 100 & $100.0 \%$ \\
\hline PALPITATION & 100 & $100.0 \%$ & 0 & $.0 \%$ & 100 & $100.0 \%$ \\
\hline DIARROHEA & 100 & $100.0 \%$ & 0 & $.0 \%$ & 100 & $100.0 \%$ \\
\hline CONSTIPATION & 100 & $100.0 \%$ & 0 & $.0 \%$ & 100 & $100.0 \%$ \\
\hline WEIGHT GAIN & 100 & $100.0 \%$ & 0 & $.0 \%$ & 100 & $100.0 \%$ \\
\hline WT LOSS & 100 & $100.0 \%$ & 0 & $.0 \%$ & 100 & $100.0 \%$ \\
\hline MENORRHAGIA & 100 & $100.0 \%$ & 0 & $.0 \%$ & 100 & $100.0 \%$ \\
\hline OLIGOMENORRHOEA & 100 & $100.0 \%$ & 0 & $.0 \%$ & 100 & $100.0 \%$ \\
\hline HIRSUTISM & 100 & $100.0 \%$ & 0 & $.0 \%$ & 100 & $100.0 \%$ \\
\hline TREMORS & 100 & $100.0 \%$ & 0 & $.0 \%$ & 100 & $100.0 \%$ \\
\hline ALCOHOL & 100 & $100.0 \%$ & 0 & $.0 \%$ & 100 & $100.0 \%$ \\
\hline PALLOR & 100 & $100.0 \%$ & 0 & $.0 \%$ & 100 & $100.0 \%$ \\
\hline ICTERUS & 100 & $100.0 \%$ & 0 & $.0 \%$ & 100 & $100.0 \%$ \\
\hline CLUBBING & 100 & $100.0 \%$ & 0 & $.0 \%$ & 100 & $100.0 \%$ \\
\hline CYANOSIS & 100 & $100.0 \%$ & 0 & $.0 \%$ & 100 & $100.0 \%$ \\
\hline LYMPHADENOPATHY & 100 & $100.0 \%$ & 0 & $.0 \%$ & 100 & $100.0 \%$ \\
\hline EDEMA & 100 & $100.0 \%$ & 0 & $.0 \%$ & 100 & $100.0 \%$ \\
\hline JVP & 100 & $100.0 \%$ & 0 & $.0 \%$ & 100 & $100.0 \%$ \\
\hline $\begin{array}{l}\text { SIGNS OF INSULIN } \\
\text { RESISTENCE }\end{array}$ & 92 & $92.0 \%$ & 8 & $8.0 \%$ & 100 & $100.0 \%$ \\
\hline $\begin{array}{l}\text { FUNDOSCOPY } \\
\text { CHANGES }\end{array}$ & 96 & $96.0 \%$ & 4 & $4.0 \%$ & 100 & $100.0 \%$ \\
\hline
\end{tabular}

\begin{tabular}{|l|l|l|l|l|l|l|l|l|}
\hline & \multicolumn{3}{|l}{ GL+ } & HP+ & NAD & \multicolumn{2}{l|}{ Total } \\
\cline { 2 - 9 } & freq & $\%$ & freq & $\%$ & freq & $\%$ & freq & $\%$ \\
\hline CVS & 0 & $.0 \%$ & 0 & $.0 \%$ & 100 & $100.0 \%$ & 100 & $100.0 \%$ \\
RS & 0 & $.0 \%$ & 0 & $.0 \%$ & 100 & $100.0 \%$ & 100 & $100.0 \%$ \\
GI & 0 & $.0 \%$ & 1 & $1.0 \%$ & 99 & $99.0 \%$ & 100 & $100.0 \%$ \\
CNS & 0 & $.0 \%$ & 0 & $.0 \%$ & 100 & $100.0 \%$ & 100 & $100.0 \%$ \\
URINE & 1 & $1.0 \%$ & 0 & $.0 \%$ & 99 & $99.0 \%$ & 100 & $100.0 \%$ \\
ANALYSIS & 1 & & 0 & & & & & \\
\hline
\end{tabular}

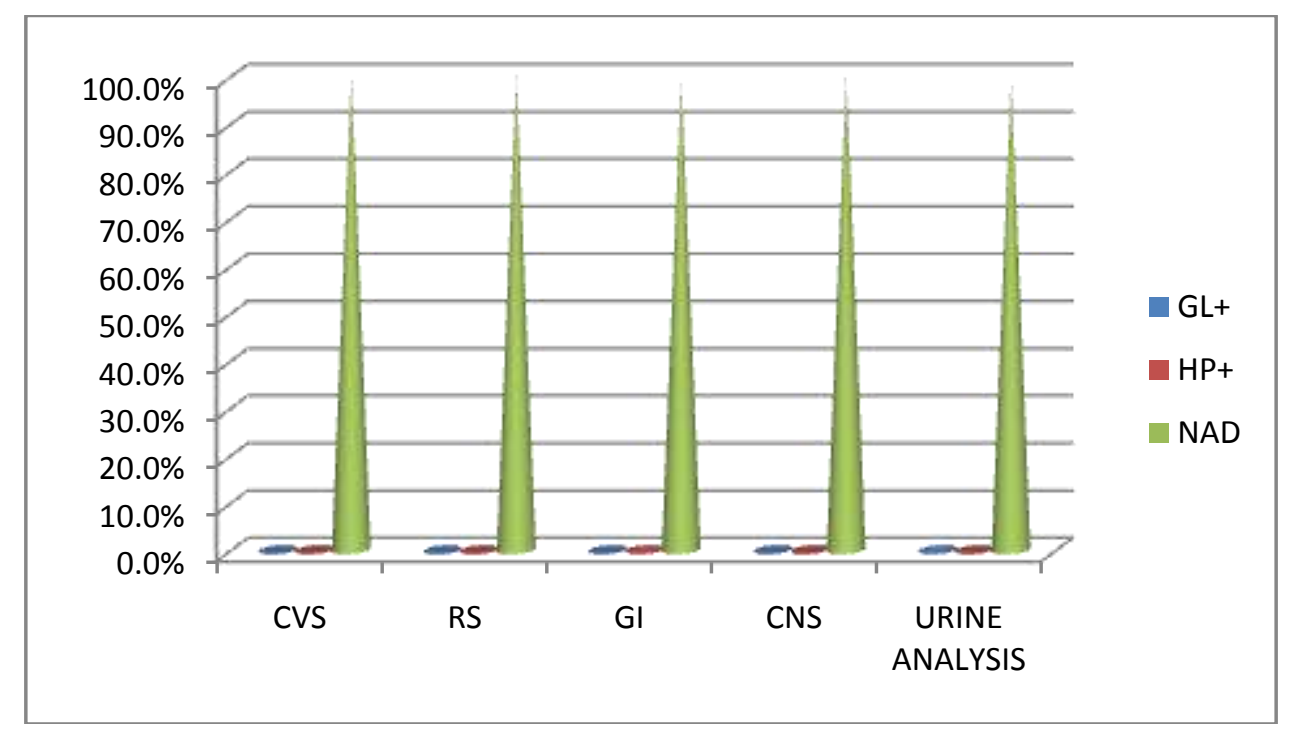

There are no pathognomic signs or symptoms in NAFLD. 


\section{ASSOCIATION WITH HYPERTENSION}

DURATION OF DM * USG-FATTY LIVER Cross tabulation

\begin{tabular}{|c|c|c|c|c|c|}
\hline & & & \multicolumn{2}{|c|}{ USG-FATTY LIVER } & \multirow[b]{2}{*}{ Total } \\
\hline & & & $\mathrm{N}$ & $\mathrm{Y}$ & \\
\hline \multirow{9}{*}{$\begin{array}{l}\text { DURATION } \\
\text { OF DM }\end{array}$} & $1-2 y r s$ & Count & 26 & 4 & 30 \\
\hline & & $\begin{array}{l}\text { \% within } \\
\text { DURATION OF DM }\end{array}$ & $86.7 \%$ & $13.3 \%$ & $100.0 \%$ \\
\hline & & $\begin{array}{l}\text { \% within } \\
\text { USG-FATTY LIVER }\end{array}$ & $35.1 \%$ & $15.4 \%$ & $30.0 \%$ \\
\hline & $3-4$ yrs & Count & 29 & 10 & 39 \\
\hline & & $\begin{array}{l}\text { \% within } \\
\text { DURATION OF DM }\end{array}$ & $74.4 \%$ & $25.6 \%$ & $100.0 \%$ \\
\hline & & $\begin{array}{l}\text { \% within } \\
\text { USG-FATTY LIVER }\end{array}$ & $39.2 \%$ & $38.5 \%$ & $39.0 \%$ \\
\hline & 5yrs and above & Count & 19 & 12 & 31 \\
\hline & & $\begin{array}{l}\text { \% within } \\
\text { DURATION OF DM }\end{array}$ & $61.3 \%$ & $38.7 \%$ & $100.0 \%$ \\
\hline & & $\begin{array}{l}\text { \% within } \\
\text { USG-FATTY LIVER }\end{array}$ & $25.7 \%$ & $46.2 \%$ & $31.0 \%$ \\
\hline \multirow[t]{3}{*}{ Total } & & Count & 74 & 26 & 100 \\
\hline & & $\begin{array}{l}\text { \% within } \\
\text { DURATION OF DM }\end{array}$ & $74.0 \%$ & $26.0 \%$ & $100.0 \%$ \\
\hline & & $\begin{array}{l}\text { \% within } \\
\text { USG-FATTY LIVER }\end{array}$ & $100.0 \%$ & $100.0 \%$ & $100.0 \%$ \\
\hline
\end{tabular}

In our study $28 \%$ of the total cases included were hypertensives. Out of which $53.6 \%$ were found to be associated with NAFLD.

\section{ASSOCIATION WITH DYSLIPIDEMIA}

\section{DYSLIPIDEMIA * USG-FATTY LIVER Cross tabulation}

\begin{tabular}{|c|c|c|c|c|c|}
\hline & & & USG-FA & LIVER & \\
\hline & & & $\mathrm{N}$ & $Y$ & Total \\
\hline DYSLIPIDEMIA & $\mathrm{N}$ & Count & 71 & 17 & 88 \\
\hline & & \% within DYSLIPIDEMIA & $80.7 \%$ & $19.3 \%$ & $100.0 \%$ \\
\hline & & $\begin{array}{l}\% \text { within USG-FATTY } \\
\text { LIVER }\end{array}$ & $95.9 \%$ & $65.4 \%$ & $88.0 \%$ \\
\hline & $\mathrm{Y}$ & Count & 3 & 9 & 12 \\
\hline & & \% within DYSLIPIDEMIA & $25.0 \%$ & $75.0 \%$ & $100.0 \%$ \\
\hline & & $\begin{array}{l}\text { \% within USG-FATTY } \\
\text { LIVER }\end{array}$ & $4.1 \%$ & $34.6 \%$ & $12.0 \%$ \\
\hline Total & & Count & 74 & 26 & 100 \\
\hline & & \% within DYSLIPIDEMIA & $74.0 \%$ & $26.0 \%$ & $100.0 \%$ \\
\hline & & $\begin{array}{l}\% \text { within USG-FATTY } \\
\text { LIVER }\end{array}$ & $100.0 \%$ & $100.0 \%$ & $100.0 \%$ \\
\hline
\end{tabular}




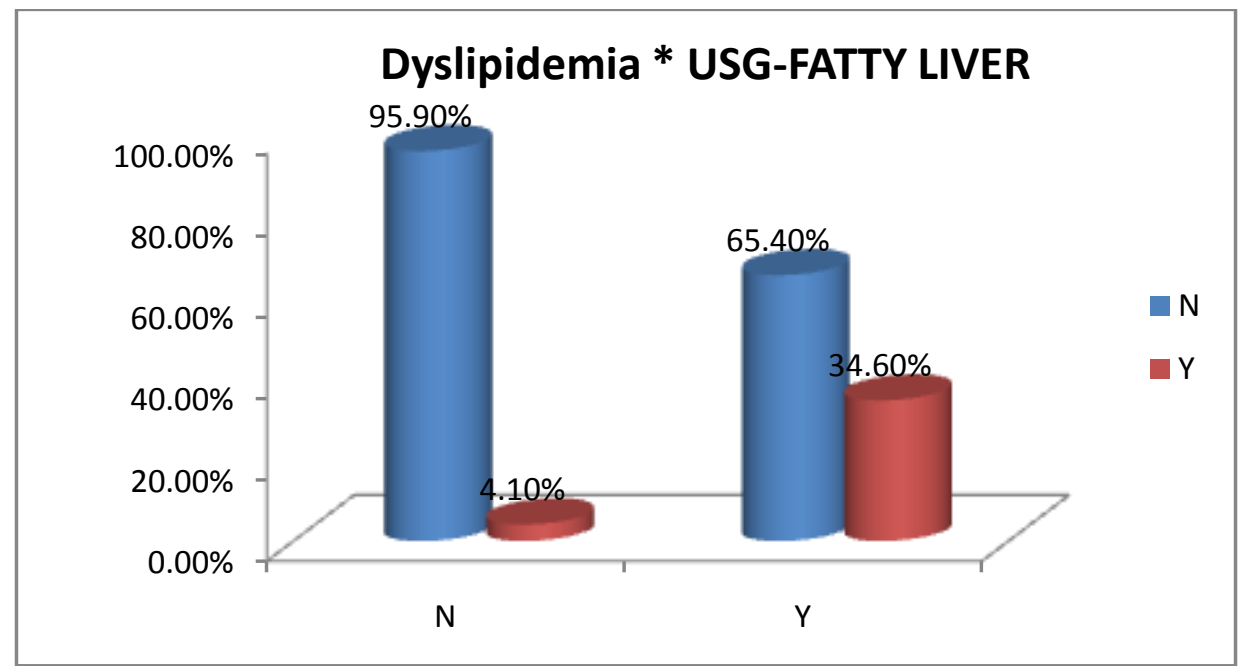

In our study, $12 \%$ of the total cases included were found to have dyslipidemia. Out of the dyslipidemics, $75 \%$ were found to have fatty liver.

\section{ASSOCIATION WITH BODY MASS INDEX}

BMI* USG-FATTY LIVER Cross tabulation

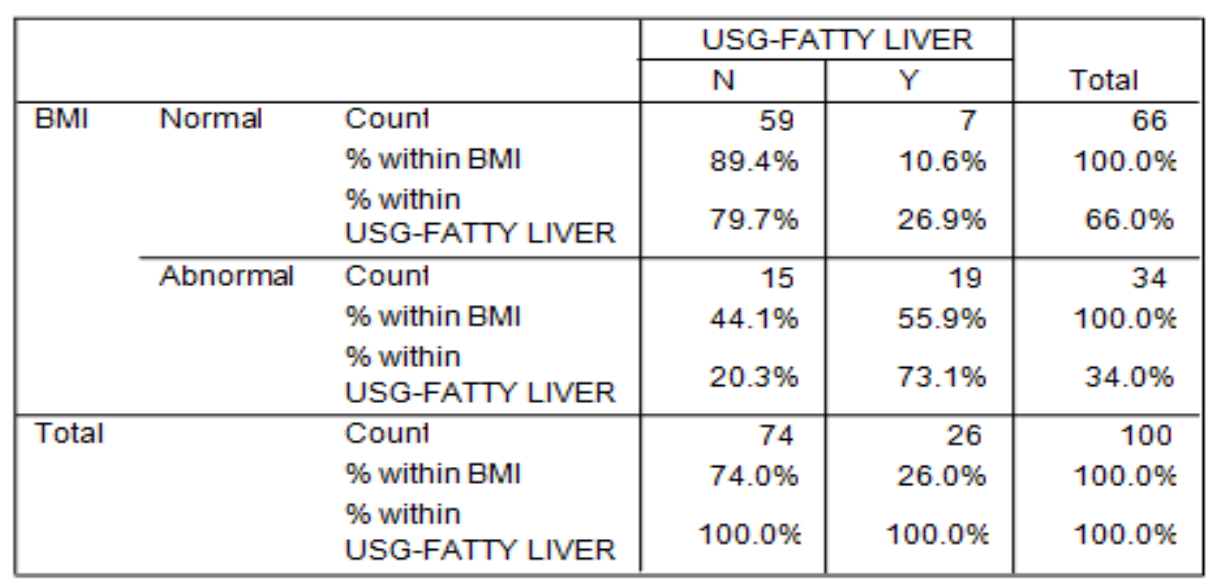

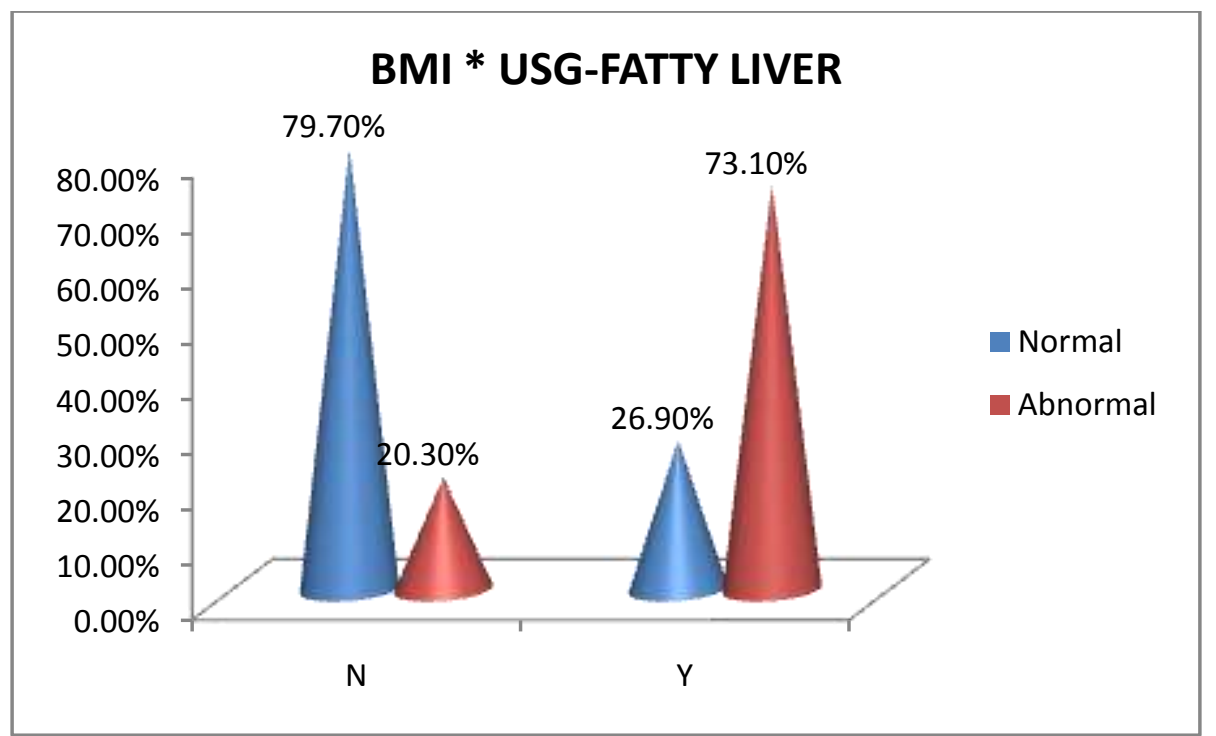

In our study, $34 \%$ of the total cases were found to have BMI $>25 \mathrm{Kg} / \mathrm{m}^{2}$. Out of which $19 \%$ were found to have fatty liver. 
ASSOCIATION WITH BILIRUBIN

BILIRUBIN * USG-FATTY LIVER Cross tabulation

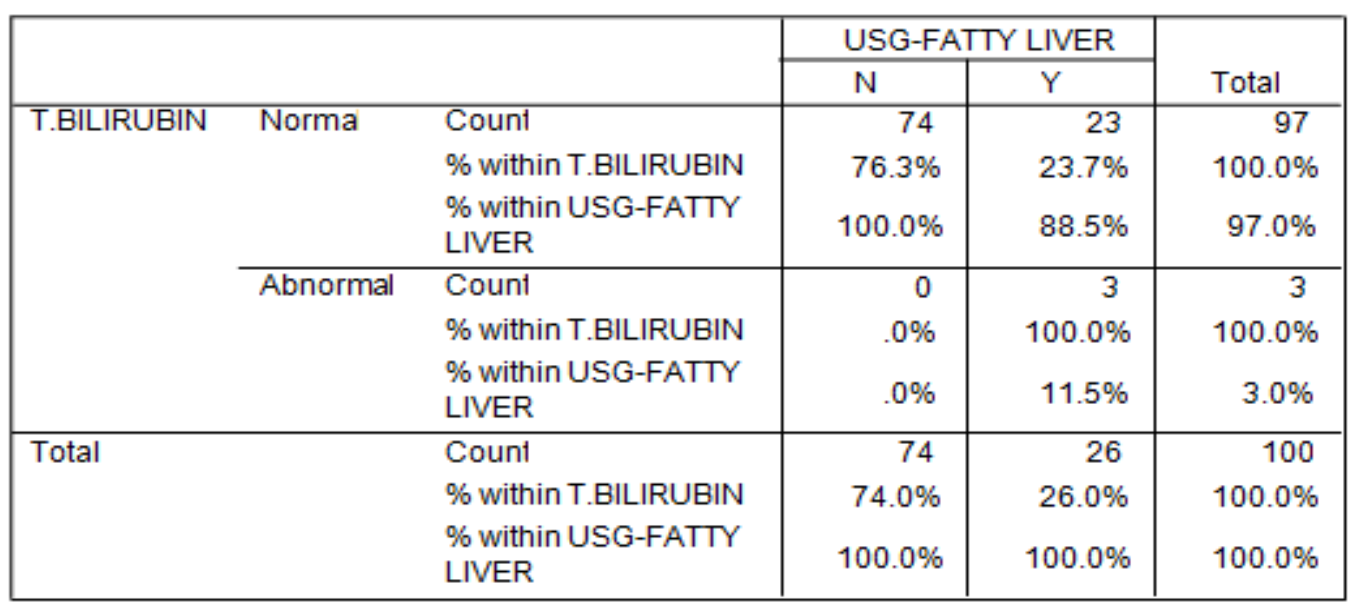

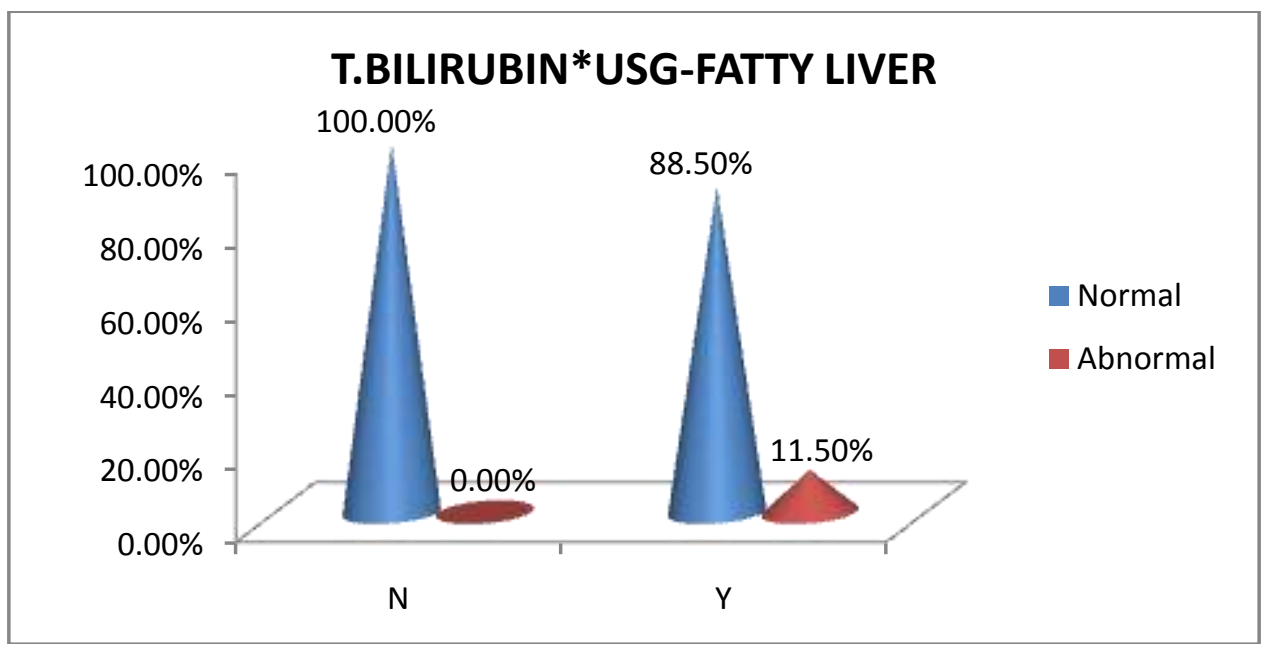

$11.5 \%$ of the patients with NAFLD had high bilirubin levels.

ASSOCIATION WITH LIVER ENZYMES SGOT * USG-FATTY LIVER Cross tabulation

\begin{tabular}{|c|c|c|c|c|c|}
\hline & \multicolumn{2}{|c|}{ USG-FATTY LIVER } & \multirow[b]{2}{*}{ Total } \\
\hline & & & $\mathrm{N}$ & $\mathrm{Y}$ & \\
\hline \multirow[t]{6}{*}{ SGOT } & Normal & Count & 64 & 10 & 74 \\
\hline & & \% within SGOT & $86.5 \%$ & $13.5 \%$ & $100.0 \%$ \\
\hline & & $\begin{array}{l}\% \text { within } \\
\text { USG-FATTY LIVER }\end{array}$ & $86.5 \%$ & $38.5 \%$ & $74.0 \%$ \\
\hline & Abnormal & Count & 10 & 16 & 26 \\
\hline & & $\%$ within SGOT & $38.5 \%$ & $61.5 \%$ & $100.0 \%$ \\
\hline & & $\begin{array}{l}\% \text { within } \\
\text { USG-FATTY LIVER }\end{array}$ & $13.5 \%$ & $61.5 \%$ & $26.0 \%$ \\
\hline \multirow[t]{3}{*}{ Total } & & Count & 74 & 26 & 100 \\
\hline & & \% within SGOT & $74.0 \%$ & $26.0 \%$ & $100.0 \%$ \\
\hline & & $\begin{array}{l}\text { \% within } \\
\text { USG-FATTY LIVER }\end{array}$ & $100.0 \%$ & $100.0 \%$ & $100.0 \%$ \\
\hline
\end{tabular}




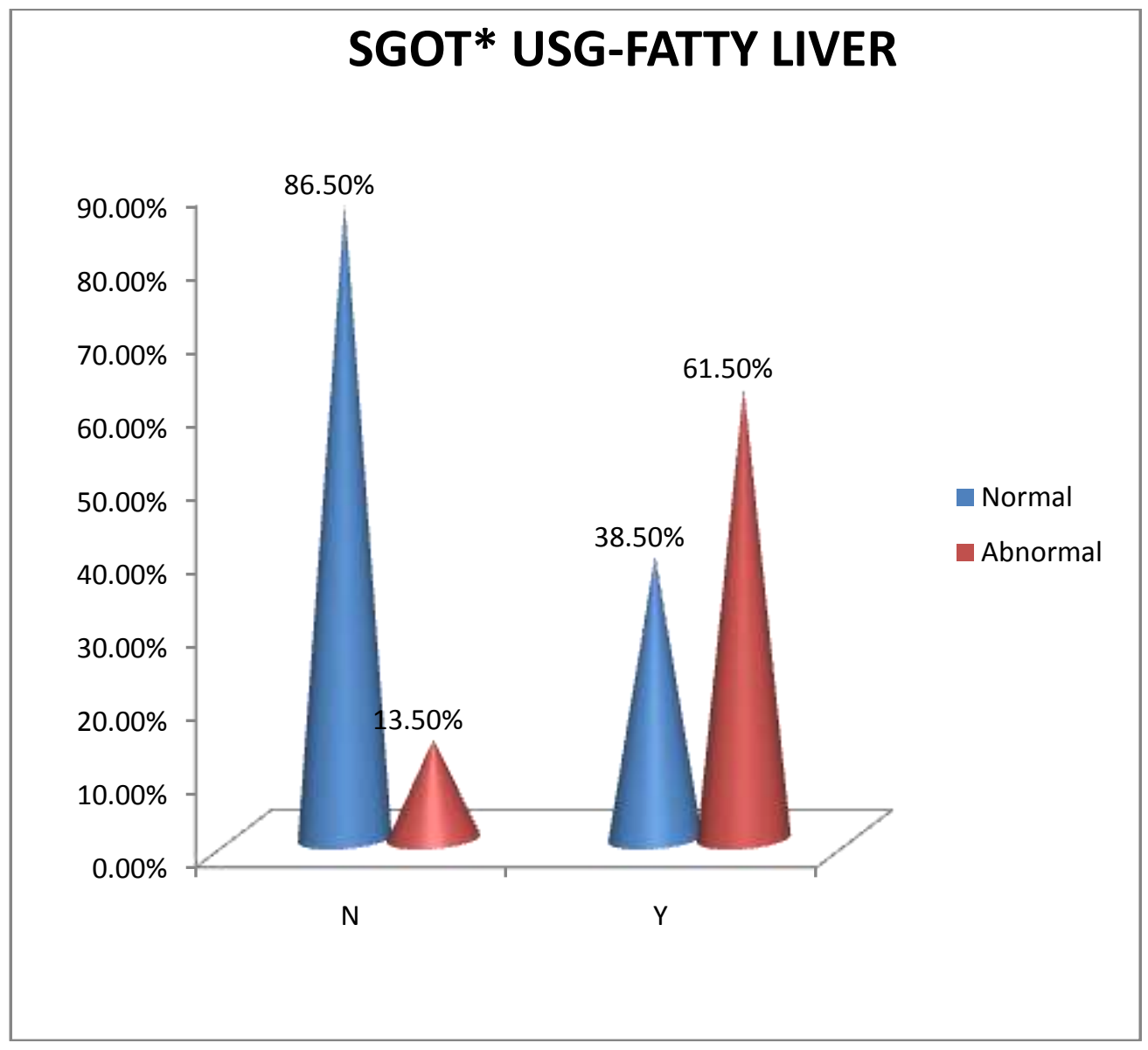

SGPT * USG-FATTY LIVER Cross tabulation

\begin{tabular}{|c|c|c|c|c|c|}
\hline & \multicolumn{2}{|c|}{ USG-FATTY LIVER } & \multirow[b]{2}{*}{ Total } \\
\hline & & & $\mathrm{N}$ & $\mathrm{Y}$ & \\
\hline \multirow[t]{6}{*}{$\overline{\text { SGPT }}$} & Normal & Count & 52 & 10 & 62 \\
\hline & & $\%$ within SGPT & $83.9 \%$ & $16.1 \%$ & $100.0 \%$ \\
\hline & & $\begin{array}{l}\text { \% within } \\
\text { USG-FATTY LIVER }\end{array}$ & $70.3 \%$ & $38.5 \%$ & $62.0 \%$ \\
\hline & Abnormal & Count & 22 & 16 & 38 \\
\hline & & $\%$ within SGPT & $57.9 \%$ & $42.1 \%$ & $100.0 \%$ \\
\hline & & $\begin{array}{l}\text { \% within } \\
\text { USG-FATTY LIVER }\end{array}$ & $29.7 \%$ & $61.5 \%$ & $38.0 \%$ \\
\hline \multirow[t]{3}{*}{ Total } & & Count & 74 & 26 & 100 \\
\hline & & $\%$ within SGPT & $74.0 \%$ & $26.0 \%$ & $100.0 \%$ \\
\hline & & $\begin{array}{l}\% \text { within } \\
\text { USG-FATTY LIVER }\end{array}$ & $100.0 \%$ & $100.0 \%$ & $100.0 \%$ \\
\hline
\end{tabular}




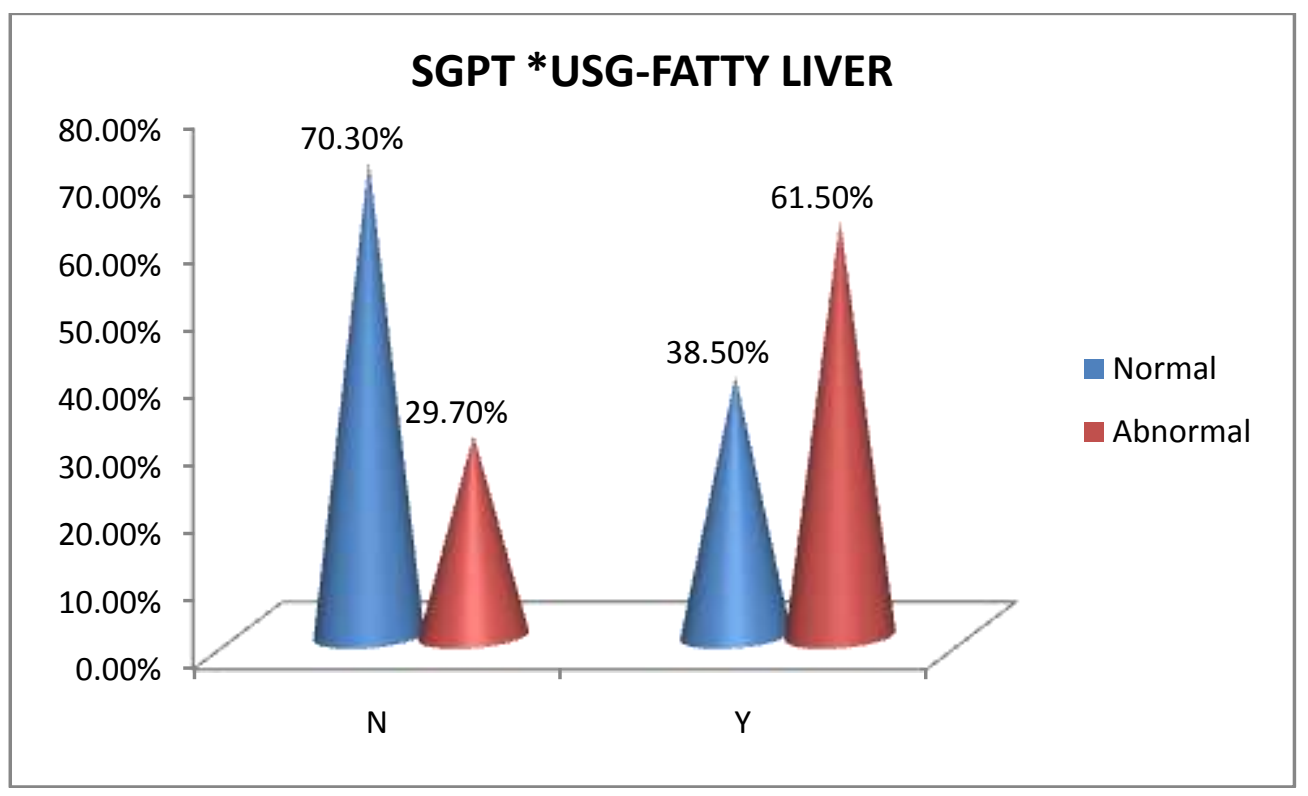

$38 \%$ of the patients with NAFLD were found to have elevated SGPT and $26 \%$ of the patients were found to have elevated SGOT.

\section{DISCUSSION:}

NAFLD represents a group of disease, characterized histologically by excessive accumulation of hepatic fat in the absence of significant alcohol consumption; with or without inflammation, varying degree of fibrosis and cirrhosis $^{32}$.

Our study on NAFLD in patients diagnosed with T2 DM was conducted on 100 inpatients and outpatients of Father Muller Medical College.

\section{PREVALENCE OF NAFLD IN TYPE 2 DIABETES MELLITUS:}

The majority of the studies on NAFLD in T2 DM population are based on histological evidence of steatosis. There are also several studies based on fatty infiltration proven by imaging. 
Study On Non Alcoholic Fatty Liver Diseases in Type 2 Diabetes Mellitus With Clinical Correlation

\begin{tabular}{|l|l|}
\hline STUDY & AGE DISTRIBUTION \\
\hline PRESENT STUDY & $41-50$ YEARS \\
\hline Hayes P et al & $41-60$ YEARS \\
\hline Vishwanathan Vet al & $61-70$ YEARS \\
\hline
\end{tabular}

However there are only very few studies involving the clinical correlation with NAFLD with biochemical as well as sonological evidence.

The overall prevalence of NAFLD in T2DM in this study was found to be $26 \%$, which is lower than the prevalence rates in different studies conducted in India- Kalra S et al which was 56.5\% and Mohan et al which was $54.5 \%$.

However the prevalence rates were found to be higher than the prevalence rates of $12.5 \%$ and $20 \%$ described by AgalS etal ${ }^{44}$.

One of the studies of NAFLD in T2 DM based on histological evidence by Banerjee $\mathrm{S}$ et al showed a much

\begin{tabular}{|l|l|}
\hline STUDY & PREVALENCE OF NAFLD IN T2DM \\
\hline Prashanth et al & $87 \%$ \\
\hline Mohan et al & $56.5 \%$ \\
\hline Kalra S et al & $54.5 \%$ \\
\hline PRESENT STUDY & $26 \%$ \\
\hline Agal S etal (2007) & $20 \%$ \\
\hline Agal S etal (2004) & $12.5 \%$ \\
\hline
\end{tabular}

higher prevalence rate of $87 \%$.

Based on the type of study, the prevalence rates were much higher in those which had histological evidence for NAFLD in comparison to those which were conducted based on biochemical and sonologicalevidence .

\section{AGE DISTRIBUTION OF NAFLD AMONG DIABETICS}

Studies in India have revealed the mean age group of patients with NAFLD in diabetes to be between 40 to 50 years.

In this study, the disease occurrence was found to be predominantly in thefourth decade.

In a similar study done in India by Kalra $\mathrm{S}$ et al, the prevalence of the disease was found to higher with increasing age and commonest in the fifth decade ${ }^{32}$.

A study conducted in Chennai by Vishwanathan $\mathrm{V}$ et al was also found to have a predominant incidence of fatty liver with diabetes in the sixth decade of life ${ }^{41}$.

\section{SEX DISTRIBUTION OF NAFLD AMONG DIABETICS}

Most of the studies in India have shown a higher prevalence of NAFLD among males than female population ${ }^{46}$.

In our study the disease incidence was equally distributed among male and femalepopulation.However a study by Kalra $\mathrm{S}$ et al revealed higher prevalence rate of disease among females $(60 \%)$ than in male $(53.4 \%)$ population ${ }^{41}$.

\section{ASSOCOATION OF HYPERTENSION, DYSLIPIDEMIA AND OBESITY WITH NAFLD}

There is an important and well established clinical association between NAFLD and HTN, diabetes, dyslipidemia, obesity. 


\section{ASSOCOATION WITH HYPERTENSION}

The association of NAFLD with HTN is well documented; systolic being more commonly associated in a study by BellentaniS et $\mathrm{al}^{44}$.

In a study by Banerjee et al, both increased systolic and diastolic blood pressure were significantly associated with NAFLD, more so with diastolic $\mathrm{BP}^{43}$.

In our study $28 \%$ of the total cases included were hypertensives. Out of which $53.6 \%$ were found to be associated with NAFLD.

In a study conducted by Kalra $S$ et al out of the 557 hypertensive patients enrolled, 336 were found to be associated with NAFLD ${ }^{45}$.

In a study by Viswanathan et al, $64.7 \%$ of the hypertensives included in the study were found to be associated with NAFLD ${ }^{41}$.

\begin{tabular}{|l|l|}
\hline STUDY & $\begin{array}{l}\text { PREVELENCE OF NAFLD AMONG } \\
\text { HYPERTENSIVES }\end{array}$ \\
\hline PRESENT STUDY & $53.6 \%$ \\
\hline Kalra S et al & $64.4 \%$ \\
\hline Viswanathan et al & $64.7 \%$ \\
\hline
\end{tabular}

\section{ASSOCIATION WITH DYSLIPIDEMIA}

In our study, $12 \%$ of the total cases included were found to have dyslipidemia. Out of the dyslipidemics , 75\% were found to have fatty liver.

In a study by Kalra $S$ et al, outof 485 patients with dyslipidemia , 311 (59.6\%) were found to have NAFLD ${ }^{41}$.

In a study by Viswanathan et al , $85.3 \%$ of the subjects with dyslipidemia were found to be associated with NAFLD ${ }^{46}$.

\begin{tabular}{|l|l|}
\hline STUDY & $\begin{array}{l}\text { PREVELENCE OF NAFLD AMONG } \\
\text { DYSLIPIDEMICS }\end{array}$ \\
\hline Viswanathan et al & $85.3 \%$ \\
\hline PRESENT STUDY & $75 \%$ \\
\hline Kalra S et al & $59.6 \%$ \\
\hline
\end{tabular}

\section{ASSOCIATION WITH BMI}

Obesity in particular central obesity has been described as one of the strongest risk factors NAFLD and fibrosis ${ }^{42}$.

In our study, $34 \%$ of the total cases were found to have BMI $>25 \mathrm{Kg} / \mathrm{m}^{2}$. Out of which $19 \%$ were found to have fatty liver.

In a study conducted in Kalra $\mathrm{S}$ et al, $53.6 \%$ of those patients with obesity enrolled in the study were found to be associated with fatty liver ${ }^{42}$.

In a study by Viswanathan et al $27.6 \%$ of the patients with BMI $>25 \%$ enrolled were found to be associated with NAFLD ${ }^{46}$

\begin{tabular}{|l|l|}
\hline STUDY & $\begin{array}{l}\text { PREVELENCE OF NAFLD AMONG CASES } \\
\text { WITH BMI }>25 \mathrm{KG} / \mathrm{M}^{2}\end{array}$ \\
\hline PRESENT STUDY & $19 \%$ \\
\hline Viswanathan et al & $27.6 \%$ \\
\hline Kalra S et al & $54.9 \%$ \\
\hline
\end{tabular}




\section{ASSOCIATION WITH THE DURATION OF TYPE 2 DIABETES MELLITUS}

The prevalence of NAFLD was also noticed to bedirectly proportional to the duration of diabetes ${ }^{44}$. In this study, the group of patients with more than 5 year duration of diabetes were found to have an incidence of $46.2 \%$. A declining trend in the incidence of NAFLD was noted with a decline in the duration of diabetes. $38.5 \%$ and $15.4 \%$ were the incidence rates in the groups with duration of diabetes 3 to 4 years and 1 to 2 years respectively.

\section{ASSOCIATION WITH LIVER ENZYMES}

Arruda MJ et al, in his study produces enough evidence to suggest that mild elevation in the liver enzymes maybe a marker for significant liver disease ${ }^{40}$.

In our study, mean ALT levels were found to be higher than AST levels.

$38 \%$ of the patients with NAFLD were found to have elevated ALT and $26 \%$ of the patients were found to have elevated AST.

\begin{tabular}{|c|c|}
\hline STUDY & ASSOCIATION BETWEEN NAFLD AND USG \\
\hline PRESENT STUDY & $26 \%$ \\
\hline BHANERJEE et al & $63.8 \%$ \\
\hline
\end{tabular}

$\mathrm{S}$ et al, conducted across 101 centers in India, the mean ALT was found to be higher than mean AST ${ }^{41} .34 .9 \%$ of the patients with NAFLD were found to have at least one abnormal aminotransferase level out of which 19\% had elevation in the ALT and 15.9\% had elevation in the AST levels. $65.1 \%$ of the patient was found to have elevation of both ALT and AST.

\begin{tabular}{|l|l|l|}
\hline & ALT & AST \\
\hline PRESENT STUDY & $38 \%$ & $26 \%$ \\
\hline Kalra S et al & $19 \%$ & $15.9 \%$ \\
\hline
\end{tabular}

However there have also been studies where there has not been significant correlation between the liver enzymes and NAFLD.

In Dallas heart study, $79 \%$ of those with hepatic steatosis had normal ALT levels. ALT levels may be normal in the presence of advanced fibrosis or cirrhosis.

\section{NAFLD AND ULTRASONOGRAPHY}

USG is by far the commonest method of diagnosing NAFLD in clinical practice.

The sensitivity of diagnosing NAFLD sonologically is found to be $83 \%$.

In our study, $26 \%$ of the patients were found to be associated with increased echogenicity of the liver suggestive of fatty liver.

Other noninvasive techniques including CT and MRI can identify hepatic steatosis. Of these MRI appears to be most promising, because its results correlate well with the degree of histologic steatosis.

\section{NAFLD AND HISTOLOGY}

The gold standard for diagnosing NAFLD is clinicopathological correlation with confirmation of steatosis by biopsy ${ }^{42}$. Liver biopsy is the only test which can reliably identify and quantify hepatic necrosis, inflammation and fibrosis. Hence it plays a very important role in staging the disease.

Recommending liver biopsy for everyone subjected of having NAFLD would not be practical. Arguments against a biopsy in everyone include the high prevalence of NAFLD, cost and potential risks with the procedure.

\section{SUMMARY}


- A total of 100 cases with type 2 diabetes mellitus were included in the study, evaluated for NAFLD and clinically correlated.

- $26 \%$ of the participants in the study were found to be associated with NAFLD which was predominantly in the fourth decade and equally distributed among males and females.

- $53.6 \%$ of the hypertensives, $75 \%$ of the patients with dyslipidemia and $19 \%$ of the patients with high BMI were found to be associated with NAFLD.

- The study also showed a significant correlation between the abnormal liver enzymes and NAFLD.

\section{LIMITATIONS}

- The study lacks of histological evidence for NAFLD in the cases included.

- Improved imaging modality like MRI spectroscopy was not used in the diagnosis of NAFLD in this study.

\section{CONCLUSION}

- This study demonstrates and clinically correlates the cluster of abnormalities and risk factors like hypertension, obesity, duration of diabetes with NAFLD.

- The association of the laboratory parameters with NAFLD also helps in the early detection of unanticipated liver disorders like NAFLD.

\section{BIBLIOGRAPHY}

1. Clark JM, Brancati FL, Diehl AM. The prevalence and an etiology of elevated aminotransferase levels in the United States. Am J Gastroenterol 2003; 98:960-7.

2. Bedogni G, Miglioli L, Masutti F, Tiribelli C, Marchesini G, Bellentani S. Prevalence of and risk factors for nonalcoholic fatty liver disease: the Dionysos Nutrition and Liver Study. Hepatology 2005; 42:44-52.

3. Medina J, Fernández-Salazar LI, García-Buey L, Moreno-Otero R. Approach to the pathogenesis and treatment of nonalcoholic steatohepatitis. Diabetes Care 2004; 27:2057-66.

4. Kotronen A, Yki-Järvinen H. Fatty liver: a novel component of the metabolic syndrome. ArteriosclerThrombVascBiol 2008; 28:27-38.

5. Fan JG, Saibara T, Chitturi S, Kim BI, Sung JJ, Chutaputti A. The Asia-Pacific Working Party for NAFLD. What are the risk factors and settings for nonalcoholic fatty liver disease in Asia Pacific?. J GastroenterolHepatol 2007; 22: 794-800.

6. Silverman JF, O'Brien KF, Long S, Leggett N, Khazanie PG, Pories WJ, et al. Liver pathology in morbidly obese patients with and without diabetes. Am J Gastroenterol 1990; 85:1349-55.

7. Duseja A, Das A, Das R, Dhiman RK, Chawla Y, Bhansali A et al. Theclinicopathological profile of Indian patients with nonalcoholic fatty liverdisease (NAFLD) is different from that in the West. Dig Dis Sci2007; 52:2368-74.

8. Marchesini G, Brizi M, Bianchi G, Tomassetti S, Bugianesi E, Lenzi M. Nonalcoholic fatty liverdisease: a feature of the metabolic syndrome. Diabetes 2001; 50:1844-50.

9. Angelico F, Del Ben M, Conti R, Francioso S, Feole K, Maccioni D et al. Non-alcoholic fatty liver syndrome: a hepatic consequence of commonmetabolic diseases. J Gastro enteral Hepatol 2003; 18:58894.

10. Kim HC, Nam CM, Jee SH, Han KH, Oh DK, Suh I. Normal serum aminotransferaseconcentration and risk of mortality from liver diseases: prospective cohortstudy. BMJ2004.24; 328:983.

11. Pratt DS, Kaplan MM. Evaluation of abnormal liver-enzyme results inasymptomatic patients. N Engl J Med 2000.27; 342:1266-71.

12. Erbey JR, Silberman C, Lydick E. Prevalence of abnormal serum alanineaminotransferase levels in obese patients and patients with type 2 diabetes. Am J Med 2000; 109:588-90.

13. Marchesini G, Brizi M, Morselli-Labate AM, Bianchi G, Bugianesi E, McCullough AJ et al. Association of nonalcoholic fatty liver disease with insulin resistance. Am J Med 1999; 107:450-5.

14. Rosen F, Roberts NR, Nichol CA. Glucocorticosteroids and transaminaseactivity. Increased activity of glutamicpyruvic transaminase in fourconditions associated with gluconeogenesis. J BiolChem 1959; 234:476-80.

15. Harrison SA, Fincke C, Helinski D, Torgerson S, Hayashi P. A pilot study oforlistat treatment in obese, non-alcoholic steatohepatitis patients. AlimentPharmacolTher 2004.15; 20:623-8.

16. Hatzitolios A, Savopoulos C, Lazaraki G, Sidiropoulos I, HaritantiP,Lefkopoulos A et al. Efficacy of omega-3 fatty acids, atorvastatin and orlistat in non-alcoholic fatty liver disease with dyslipidemia. Indian J Gastro enteral 2004; 23:131-4. 
17. Zelber-Sagi S, Kessler A, Brazowsky E, Webb M, Lurie Y, Santo M.A double-blind randomized placebocontrolled trial oforlistat for the treatment of nonalcoholic fatty liver disease. ClinGastro enteral Hepatol2006 ; 4:639-44.

18. Uygun A, Kadayifci A, Isik AT, Ozgurtas T, Deveci S, Tuzun A et al. Metformin in the treatment of patients with non-alcoholicsteatohepatitis. Aliment PharmacolTher 2004; 19:537-44.

19. Marchesini G, Brizi M, Bianchi G, Tomassetti S, Zoli M, MelchiondaN.Metformin in non-alcoholic steatohepatitis. Lancet 2001.15;358:893-4.

20. Bajaj M, Suraamornkul S, Piper P, Hardies LJ, Glass L, CersosimoE at al. Decreased plasma adiponectinconcentrations are closely related to hepatic fat content and hepatic insulinresistance in pioglitazone treated type 2 diabetic patients. J ClinEndocrinolMetab 2004; 89:200-6.

21. Kim HC, Nam CM, Jee SH, Han KH, Oh DK, Suh I. Normal serum aminotransferaseconcentration and risk of mortality from liver diseases: prospective cohortstudy. BMJ 2004.24;328:983.

22. Pratt DS, Kaplan MM. Evaluation of abnormal liver enzyme results inasymptomatic patients. N Engl J Med 2000;342:1266-71.

23. Erbey JR, Silberman C, Lydick E. Prevalence of abnormal serum alanineaminotransferase levels in obese patients and patients with type 2 diabetes. Am J Med 2000; 109:588-90.

24. Marchesini G, Brizi M, Morselli-Labate AM, Bianchi G, Bugianesi E, McCullough AJ et al. Association of nonalcoholic fatty liver disease with insulin resistance. Am J Med 1999; 107:450-5.

25. Petta $S$, Muratore $C$, Craxì $A$. Non-alcoholic fatty liver disease pathogenesis: the present and the future. Dig Liver Dis 2009; 41:615-25.

26. Bedogni G, Miglioli L, Masutti F, Tiribelli C, Marchesini G, BellentaniS.Prevalence of and risk factors for nonalcoholic fatty liver disease: the nutrition and liver study. Hepatology 2005; 42:44-52.

27. Hsiao PJ, Kuo KK, Shin SJ, Yang YH, Lin WY, Yang JF et al. Significant correlations between severe fatty liver and risk factors for metabolic syndrome. J GastroenterolHepatol 2007; 22:2118-23.

28. Day CP, James OF. Steatohepatitis: a tale of two "hits"? . Gastroenterology J 1998; 114:842-5.

29. Hatzitolios A, Savopoulos C, Lazaraki G, Sidiropoulos I, HaritantiP,Lefkopoulos A et al. Efficacy of omega-3 fatty acids, atorvastatin and orlistat in non-alcoholic fatty liver disease with dyslipidemia. Indian J Gastroenterol 2004; 23:131-4.

30. Younossi ZM, Gramlich T, Matteoni CA, Boparai N, McCullough AJ. Nonalcoholicfatty liver disease in patients with type 2 diabetes. ClinGastroenterolHepatol 2004; 2:262-5.

31. Powell EE, Cooksley WG, Hanson R, Searle J, Halliday JW, Powell LW. Thenatural history of nonalcoholic steatohepatitis: a follow-up study of forty-two patients for up to 21 years. Hepatology 1990; 11:74-80.

32. Mofrad P, Contos MJ, Haque M, Sargeant C, Fisher RA, Luketic VA et al . Clinical and histologic spectrum ofnonalcoholic fatty liver disease associated with normal ALT values. Hepatology 2003; 37:1286-92.

33. Bacon BR, Farahvash MJ, Janney CG, Neuschwander-Tetri BA. Nonalcoholicsteatohepatitis: an expanded clinical entity. Gastroenterology 1994;107:1103-9.

34. Seist G, Schiele F, Galteau M, Panek E, Steinmertz J, Fagnani F et al. Aspartate aminotransferase and alanine aminotransferase activities in plasma: statistical distributions, individual variations, and reference values. ClinChem1975;21:1077-87.

35. Sherman KE. Alanine aminotransferase in clinical practice. A review. Arch Intern Med 1991;151:260-5.

36. Pratt DA, Kaplan MM. Evaluation of abnormal liver-enzyme results in asymptomatic patients. $\mathrm{N}$ Engl $\mathrm{J}$ Med 2000; 342:1266-71.

37. Prati D, Taioli E, Zanella A, Torre ED, Butelli S, Del Vecchio E et al. Updated definitions of healthy ranges for serum alanine aminotransferase levels. Ann Intern Med 2002; 137:1-9.

38. Chobanian AV, Bakris GL, Black HR, Cudhman WC, Green LA, Izzo JL et al. The seventh report of the joint national committee on prevention, detection, evaluation, and treatment of high blood pressure. JAMA 2003;289:2560-72.

39. Easton DF, Peto J, Babiker AG. Floating absolute risk: an alternative to relative risk in survival and casecontrol analysis avoiding an arbitrary reference group. Stat Med 1991;10:1025-35.

40. Hultcrantz R, Claumann H, Lindberg G, Nilsson L. Liver investigation in 149 asymptomatic patients with moderately elevated activities of serum aminotransferase. Scand J Gastroenterol 1986;21:109-13.

41. Mohan V, Farooq S, Deepa M, Ravikumar R, Pitchumoni CS. Prevalence ofnon-alcoholic fatty liver disease in urban south Indians in relation to differentgrades of glucose intolerance and metabolic syndrome. Diabetes Res ClinPract 2009; 84:84-91.

42. Gupte $\mathrm{P}$, Amarapurkar D, Agal S, Baijal R, Kulshrestha P, Pramanik S et al. Non-alcoholic steatohepatitis in type 2 diabetes mellitus. J GastroenterolHepatol 2004; 19:854-8. 
43. Prashanth M, Ganesh HK, Vima MV, John M, Bandgar T, Joshi SR et al. Prevalence of nonalcoholic fattyliver disease in patients with type 2 diabetes mellitus. J Assoc PhysiciansIndia 2009 ;57:205-10.

44. Singh SP, Nayak S, Swain M, Rout N, Mallik RN, Agrawal O et al.Prevalence of nonalcoholic fatty liver disease in coastal eastern India: aPreliminaryultrasonographic survey. Trop Gastro enteral 2004;25:76-9.

45. Uchil D, Pipalia D, Chawla M, Patel R, Maniar S, Narayani et al.Non-alcoholic fatty liver disease (NAFLD)-the hepatic component of metabolicsyndrome. J Assoc Physicians India 2009;57:201-4.

46. Amarapurkar DN, Amarapurkar AD. Nonalcoholic steatohepatitis:clinicopathological profile. J Assoc Physicians India 2000; 48:311-3. 